\title{
RESEARCH PAPER \\ INFLUENCE OF CALCIUM AND MAGNESIUM BASED FERTILIZERS ON FUNGAL DISEASES, PLANT GROWTH PARAMETERS AND FRUIT QUALITY OF THREE VARIETIES OF TOMATO (SOLANUM LYCOPERSICUM)
}

\author{
J. Aghofack-Nguemezi, G. Tsopmbeng Noumbo and C. Ndille Nkumbe \\ Department of Plant Biology, Faculty of Sciences, University of Dschang, \\ P. O. Box 67 Dschang, Cameroon. \\ Corresponding author:aghofack@yahoo.fr
}

\begin{abstract}
Notwithstanding the important roles of calcium and magnesium ions in plant growth and development, the use of fertilizers containing them is not yet a common agricultural practice in Cameroon. Such fertilizers were applied on the soil and leaves of three most cultivated varieties of tomato in the Western Highlands of Cameroon. The effects of these treatments on plant health, growth, development, and yield and fruit quality were determined. The combination of soil application of calcium nitrate and foliar sprays of fertilizer containing calcium $\left(T_{1}\right)$ led to significant reductions of the severity and incidence of Phytophthora infestans and Septoria lycopersici on leaves of Rio Grande and Rio de Grenier tomato plants seven days after the first foliar application (d.a.f.a) of liquid fertilizers. At the same time significant reductions in the incidence and severity of $S$. lycopersici were observed on leaves of Roma plants previously treated with a solution of the fertilizer containing magnesium $\left(\mathrm{T}_{2}\right)$ or simultaneously treated with calcium and magnesium solutions $\left(T_{3}\right)$. Twenty-one d.a.f.a there were reductions in the severity of Alternaria solani on leaves of Rio Grande, Rio de Grenier and Roma plants that previously received $T_{3}$. Applications of $T_{3}$ also led to the reduction of the incidence and severity of Fulvia fulva on the leaves of both Rio Grande and Rio de Grenier 21 d.a.f.a. $T_{3}$ was very effective in enhancing the growth in length and yield of Rio Grande and Rio de Grenier plants. The green-life of fruits produced by these two tomato varieties that received $T_{1}$ was respectively 10 and 6 days longer than that of control fruits. $T_{2}$ prolonged the shelf-life of fruits from those varieties by 4 and 12 days respectively. On the whole, Rio Grande and Rio de Grenier plant were the tomato varieties whose health, growth, development, yield and fruit quality parameters were the most positively affected by treatments with fertilizers containing calcium oder magnesium. Roma tomato plants were affected to a lesser extent by these treatments. These results could be interpreted in terms of a temporal shift in the resistance of tomato plants to $P$. infestans and $S$. lycopersici on the one hand and A. solani and F. fulva on the other hand and also in terms of similarities of responses of closely related tomato varieties to fertilizers.
\end{abstract}

Keywords: Calcium, fungal diseases, green-life, magnesium, shelf-life, Solanum lycopersicum 


\section{Aghofack-Nguemezi et al.}

\section{INTRODUCTION}

Calcium ion $\left(\mathrm{Ca}^{2+}\right)$ is involved in a wide range of processes in plants including responses to infections (Zook et al., 1987), flower induction (Friedman et al., 1989), fruit yield (Hao and Papadopoulos, 2004) and conservation (Park et al., 2005). At the cellular level it is well established that $\mathrm{Ca}^{2+}$ plays an important role in the maintenance of membrane stability, the firmness of cell wall and cell integrity (Hepler, 2005; Leshem, 1991; Hepler and Wayne, 1985). Calcium ion may also stimulate the accumulation of phytoalexin, a compound known to be implicated in the defense mechanisms of plants as a result of fungal attacks (Zook et al., 1987). Synergistically to calcium, the magnesium ion $\left(\mathrm{Mg}^{2+}\right)$ activates enzymes that catalyze processes such as respiration, photosynthesis, synthesis of DNA and RNA and is part of the ring structure of the chlorophyll molecule (Taiz and Zeiger, 2006). From results of the measurement of $\mathrm{Mg}^{2+}$ fluorescence in the apical meristems of Pharbitis nil, Kobayashi et al. (2006) suggested that $\mathrm{Mg}^{2+}$ plays an important role in flower induction.

Despite the multifunctional roles of $\mathrm{Ca}^{2+}$ and $\mathrm{Mg}^{2+}$ in plant growth and development, fruit maturation, ripening and conservation, the use of fertilizers containing these ions is not yet, to the best of our knowledge, a common agricultural practice in the Western Highlands of Cameroon. There is thus an urgent need of popularizing these types of fertilizers in the West region in particular and other regions of Cameroon where tomato crops and other vegetables are widely grown. It is worth noting that the efficiency of fertilizers containing calcium and/or magnesium depends on the mode of application. Indeed, while the application of $\mathrm{Ca}^{2+}$ to soils is not very efficient, its application to leaves as sprays can in some cases have agronomic advantages due to the reduction of the lag-time between the application and uptake. This is important especially during the phase of rapid growth of plants. Foliar sprays of fertilizer solutions could circumvent the problem of restricted uptake of the nutrient from the soil
(Taiz and Zeiger, 2006).

Previous work has shown that soil application of calcium nitrate at $200 \mathrm{~kg} / \mathrm{ha}$ in combination with foliar spray of solutions containing $\mathrm{Ca}^{2+}$ or $\mathrm{Mg}^{2+}$ lead to the prolongation of the green-life and shelf-life of tomato fruits of the variety Rio Grande (Aghofack-Nguemezi and Tatchago, 2010). The present study was undertaken to further investigate the influence of simultaneous applications of calcium nitrate at $200 \mathrm{~kg} / \mathrm{ha}$ on the soil and foliar sprays of fertilizers containing $\mathrm{Ca}^{2+}$ and $\mathrm{Mg}^{2+}$ on fungal diseases, the growth and development of plants, the quality of fruits produced by the three most cultivated varieties of tomato in the Western Highlands of Cameroon - Rio Grande, Rio de Grenier and Roma Savana.

\section{MATERIALS AND METHODS Study site}

The research was conducted at the Experimental Farm of the Faculty of Agronomy and Agricultural Sciences of The University of Dschang in Cameroon. Dschang is located at $5^{\circ} 26^{\prime} \mathrm{N}$ latitude, $10^{\circ} 26^{\prime} \mathrm{E}$ longitude and $1400 \mathrm{~m}$ altitude. The work was carried out from April 2011 to October 2011. The experimental period coincided with the rainy season.

\section{Experimental design and plant material}

Seeds of three varieties of tomato (Solanum lycopersicum), Rio Grande, Roma Savana and Rio de Grenier from the firms Tehnsisem (France) and Baddar (Morocco)were sown in nursery beds. The soil was enriched with hen droppings at the dose of $1 \mathrm{~kg} / \mathrm{m}^{2}$ and was also fertilized with urea and N-P-K (20-10-10) both at $70 \mathrm{~g} / \mathrm{m}^{2}$. Seedlings in the nursery were treated with the fungicide Ivory 80 ( $80 \%$ mancozebe) after every rainfall. The plot used for transplanting tomato seedlings had not been grown with any Solanaceaous crop for the past three years. Before transplanting the seedlings, holes were dug in rows spaced by $0.5 \mathrm{~m}$ apart with $0.4 \mathrm{~m}$ between holes. Each hole was then treated with $1.48 \mathrm{~g}$ of the insecticidenematicide Furaplant 10G (10\% carbofuran) 
and filled with $40 \mathrm{~g}$ of chicken droppings. Plots were fertilized with N-P-K (20-10-10) at 24.3 $\mathrm{kg} / \mathrm{ha}$. Seedlings were transferred to the experimental plot 30 days after sowing when young plants had 4-5 true leaves. A complete randomized block design was used with four replications. Control plants received only N-P-K (2010-10) in the soil whereas other plants further received either calcium nitrate at $200 \mathrm{~kg} / \mathrm{ha}$ in the soil and foliar sprays of the liquid fertilizer containing $\mathrm{Ca}^{2+}$ at $3 \mathrm{ml} / 1$ (LFCA, $\mathrm{T}_{1}$ ), calcium nitrate at $200 \mathrm{~kg} / \mathrm{ha}$ and foliar sprays of the liquid fertilizer containing $\mathrm{Mg}^{2+}$ at $3 \mathrm{ml} / \mathrm{l}$ (LFMG, $\mathrm{T}_{2}$ ) or a combination of LFCA and LFMG $\left(\mathrm{T}_{3}\right)$. The liquid fertilizers were of the trademark Manvert (BIOVERT, Spain). The Manvert ${ }^{\mathrm{TM}}$ solutions were sprayed on the aerial parts of tomato plants once in a week from 24 days after transplanting onwards till the harvest of the first mature fruits. All plants were staked and watered in case of need. They were treated with the insecticide Cypercot (cypermethrine 100 EC) and the fungicides Ivory $80 \quad(80 \%$ mancozebe) or Beauchamp ( $8 \%$ metalaxy and $64 \%$ mancozebe).

\section{Evaluation of fungal diseases}

The Assessment of fungal diseases started seven days after the first treatment of plants with liquid fertilizers. The disease incidence was determined as the percentage of plants with symptoms per plot whereas the disease severity was scored in each plot by using a modified formula grading scheme from Merritt et al. (1999). Diseases were identified on the basis of field symptoms followed by laboratory diagnosis in plant pathology laboratory of the University of Dschang. Diseased plant organs were identified directly with the aid of amicroscope or after spore induction or pathogen culture (Streets, 1982; Fontem, 1993).

Determination of the period between the transplantation and flowering of $50 \%$ of plants or formation of the first fruits

The period (in days) between the transplantation and flowering of $50 \%$ of tomato plants or the first fruiting was determined using five ran- domly selected plants in the middle rows of each plot.

\section{Determination of the height of plants and crop yield}

Plants height was measured from the first branching to the apex on the ninth week after pricking out. Fresh tomato fruits were weighed and dried in an oven at $65^{\circ} \mathrm{C}$ for five days. The fruits were further dried at $105^{\circ} \mathrm{C}$ for 24 hours. They were then weighed for the determination of dry matter weight according to Chapman (1976). The crop yield was obtained by calculating the total fresh weight of tomato fruits harvested in all the plots that received the same treatment.

\section{Determination of calcium and magnesium contents}

Fresh tomato fruits were dried in an oven at $105^{\circ} \mathrm{C}$ for $24 \mathrm{hr}$. One gram of the dried samples was then calcined at $405^{\circ} \mathrm{C}$ for $24 \mathrm{hr}$. Ten milliliters of 1 nitric acid solution were added to the ash and the mixture was heated till the evaporation of half of the volume. The mixture was then completed to $50 \mathrm{ml}$ with distilled water. This solution was further threefold diluted before use. $\mathrm{Ca}^{2+}$ and $\mathrm{Mg}^{2+}$ contents were determined by the complexometric method as described by Pauwels et al. (1992).

Determination of the green-life and shelf-life Tomato fruits at mature green stage were harvested and stored at $25^{\circ} \mathrm{C}$. The green-life was assessed in terms of the number of days elapsed between the mature green stage at harvest and the commencement of ripening (Dadzie and Ochard, 1997) of $100 \%$ of tomato fruits in each lot. The shelf-life was considered as the length of time between the red-ripe stage and the trickling of $100 \%$ of fruits.

\section{Statistical analysis}

This analysis was done with the SPSS software version 12.0 (IBM, Cambridge, USA). Group comparisons were made using One-way Analysis of Variance (ANOVA) to see if variations among the means of parameters from various 


\section{Aghofack-Nguemezi et al.}

treatments were significantly different. The Duncan Multiple Rang Test was used to compare means differences, whereby a $\mathrm{P}$ value of $<0.05$ was considered statistically significant.

\section{RESULTS AND DISCUSSION Plant health}

Seven days after the first foliar application (d.a.f.a) of liquid fertilizers containing $\mathrm{Ca}^{2+}$ $\left(\mathrm{T}_{1}\right)$, untreated Rio de Grenier plants were significantly more infected $(66.67 \%$ and $20.0 \%$ incidence respectively with $51.67 \%$ and $33.33 \%$ severity) by late blight induced by Phytophthora infestans and leaf spot induced by Septoria lycopersici than treated plants (26.67\% and $0.0 \%$ incidence respectively with $30.0 \%$ and $25.0 \%$ severity) (Table 1). Application of liquid fertilizer containing $\mathrm{Mg}^{2+}\left(\mathrm{T}_{2}\right)$ or simultaneous applications of $\mathrm{T}_{1}$ and $\mathrm{T}_{2}\left(\mathrm{~T}_{3}\right)$ reduced septoria leaf infection in Roma variety 7 d.a.f.a compared to untreated control plants. The incidence of $S$. lycopersici was significantly lower in Roma plants that previously received $\mathrm{T}_{2}(0.0 \%)$ or $\mathrm{T}_{3}(0.0 \%)$ than control plants $(20.0 \%)$. Moreover, the severity of $S$. lycopersici 7 d.a.f.a of any of all the three treatments applied depressed on leaves of treated Roma plants $(26.67 \%, 25.0 \%$ and $25.0 \%$ respectively) compared to controls $\left(\mathrm{T}_{0}\right)(31.37 \%)$.

There was no significant effect of mineral fertilizers applied on the incidence and severity of early blight (due to Alternaria solani) and leaf mould (caused by Fulvia fulva) on the three tomato varieties studied 7 d.a.f.a (Table 1). Also, no significant effect of $\mathrm{T}_{1}, \mathrm{~T}_{2}$ or $\mathrm{T}_{3}$ on the incidence as well as the severity of Alternaria solani, Fulvia fulva and Phytophthora infestans could be observed 14 d.a.f.a of liquid fertilizers with all the three tomato varieties tested. At the same period, the incidence and severity of $S$. lycopersici on Roma plants that had previously been sprayed with $\mathrm{T}_{2}(0.0 \%)$ and $\mathrm{T}_{3}(0.0 \%)$ were significantly lower than those observed on the control plants $(20.0 \%)$ (Table 2$)$.

There was no significant difference in the early blight incidence or the three varieties tested 21 d.a.f.a of liquid fertilizers. Nevertheless, the degree of severity of early blight infection on the three tomato varieties that previously received $\mathrm{T}_{3}$ was lesser $(86.67 \%, 80.0 \%$ and $91.67 \%$ respectively) than control plants $\left(95.0 \%, 88.0 \%\right.$ and $95.0 \%$ respectively). $\mathrm{T}_{3}$ was also very effective in inducing the resistance of Rio Grande plants against leaf mould as shown by the significant differences in its incidence and severity between control $(26.67 \%$ and $45.0 \%$ respectively) and treated plants $(0.0 \%$ and $25.0 \%$ respectively ) 21 d.a.f.a.

All the three types of mineral fertilizers applied significantly decreased the incidence $(20.0 \%$, $20.0 \%$ and $6.67 \%$ respectively) as well severity $(40.0 \%, 40.0 \%$ and $30.0 \%)$ of leaf mould fungi on treated Rio de Grenier plants 21 d.a.f.a as compared to control tomato plants $(40.0 \%$ incidence and $55.0 \%$ severity). Roma plants that received $\mathrm{T}_{2}$ were significantly more resistant to $F$. fulva than control plants 21 d.a.f.a. with regard to significant decreases in the incidence $(0.0 \%)$ and severity $(25.0 \%)$ of this pathogen when compared to control plants $(13.33 \%$ incidence and $38.33 \%$ severity). No significant effects of mineral fertilizers tested on the incidence and severity of $P$. infestans and $S$. lycopersici could be observed on leaves of all the three tomato varieties studied 21 d.a.f.a. of liquid fertilizers (Table 3).

Application of mineral fertilizers depressed the severity of $S$. lycopersici on tomato leaves.The reduction of pathogen severity caused by several fungi has been reported to be enhanced by calcium fertilization (Percival and Haynes, 2009). This reduction could be due to some resistance mechanism developed in mineral treated plants. Although this study did not investigate the mechanistic basis of enhanced resistance, Percival and Haynes (2009) suggested that one or more biochemical mechanisms could be involved. Calcium foliar treatments are known to increase resistance to many fungal diseases by improving the structural integrity of the cell wall and middle lamella that physically increased cell wall strength 
Table 1: Effects of calcium and magnesium containing fertilizers on the incidence and severity of tomato fungal diseases seven days after the first foliar application of liquid fertilizers

\begin{tabular}{|c|c|c|c|c|c|c|}
\hline \multirow{3}{*}{$\begin{array}{l}\text { Fungi types and } \\
\text { treatments }\end{array}$} & \multicolumn{6}{|c|}{ Tomato varieties, incidence and severity of the fungal diseases } \\
\hline & \multicolumn{2}{|c|}{ Rio Grande } & \multicolumn{2}{|c|}{ Rio de Grenier } & \multicolumn{2}{|c|}{ Roma Savana } \\
\hline & $\begin{array}{l}\text { Incidence } \\
(\%)\end{array}$ & $\begin{array}{l}\text { Severity } \\
(\%)\end{array}$ & $\begin{array}{l}\text { Incidence } \\
(\%)\end{array}$ & $\begin{array}{l}\text { Severity } \\
(\%)\end{array}$ & $\begin{array}{c}\text { Incidence } \\
(\%)\end{array}$ & $\begin{array}{l}\text { Severity } \\
(\%)\end{array}$ \\
\hline \multicolumn{7}{|l|}{ Alternaria solani } \\
\hline $\mathrm{T}_{0}$ & $100^{\mathrm{a}}$ & $90.0^{\mathrm{a}}$ & $100^{\mathrm{a}}$ & $85.0^{\mathrm{a}}$ & $100^{\mathrm{a}}$ & $81.67^{\mathrm{a}}$ \\
\hline $\mathrm{T}_{1}$ & $100^{\mathrm{a}}$ & $81.67^{\mathrm{a}}$ & $100^{\mathrm{a}}$ & $85.0^{\mathrm{a}}$ & $100^{\mathrm{a}}$ & $86.67^{\mathrm{a}}$ \\
\hline $\mathrm{T}_{2}$ & $100^{\mathrm{a}}$ & $75.0^{\mathrm{a}}$ & $100^{\mathrm{a}}$ & $83.33^{\mathrm{a}}$ & $100^{\mathrm{a}}$ & $85.0^{\mathrm{a}}$ \\
\hline $\mathrm{T}_{3}$ & $100^{\mathrm{a}}$ & $83.33^{\mathrm{a}}$ & $100^{\mathrm{a}}$ & $86.67^{\mathrm{a}}$ & $100^{\mathrm{a}}$ & $91.67^{\mathrm{a}}$ \\
\hline \multicolumn{7}{|l|}{ Fulvia fulva } \\
\hline $\mathrm{T}_{0}$ & $0.0^{\mathrm{a}}$ & $25.0^{\mathrm{a}}$ & $0.0^{\mathrm{a}}$ & $25.0^{\mathrm{a}}$ & $0.0^{\mathrm{a}}$ & $25.0^{\mathrm{a}}$ \\
\hline $\mathrm{T}_{1}$ & $0.0^{\mathrm{a}}$ & $25.0^{\mathrm{a}}$ & $0.0^{\mathrm{a}}$ & $25.0^{\mathrm{a}}$ & $0.0^{\mathrm{a}}$ & $25.0^{\mathrm{a}}$ \\
\hline $\mathrm{T}_{2}$ & $0.0^{\mathrm{a}}$ & $25.0^{\mathrm{a}}$ & $0.0^{\mathrm{a}}$ & $25.0^{\mathrm{a}}$ & $0.0^{\mathrm{a}}$ & $25.0^{\mathrm{a}}$ \\
\hline $\mathrm{T}_{3}$ & $0.0^{\mathrm{a}}$ & $25.0^{\mathrm{a}}$ & $0.0^{\mathrm{a}}$ & $25.0^{\mathrm{a}}$ & $0.0^{\mathrm{a}}$ & $25.0^{\mathrm{a}}$ \\
\hline \multicolumn{7}{|c|}{ Phytophthora infestans } \\
\hline $\mathrm{T}_{0}$ & $53.33^{\mathrm{b}}$ & $50.0^{\mathrm{b}}$ & $66.67^{\mathrm{a}}$ & $51.67^{\mathrm{a}}$ & $46.67^{\mathrm{b}}$ & $48.33^{\mathrm{b}}$ \\
\hline $\mathrm{T}_{1}$ & $80.0^{\mathrm{a}}$ & $63.33^{\mathrm{a}}$ & $26.67^{b}$ & $30.0^{\mathrm{b}}$ & $73.33^{\mathrm{b}}$ & $55.0^{\mathrm{b}}$ \\
\hline $\mathrm{T}_{2}$ & $66.67^{\mathrm{b}}$ & $53.33^{\mathrm{b}}$ & $73.33^{\mathrm{a}}$ & $55.0^{\mathrm{a}}$ & $93.33^{\mathrm{a}}$ & $66.67^{\mathrm{a}}$ \\
\hline $\mathrm{T}_{3}$ & $40.0^{\mathrm{b}}$ & $36.67^{\mathrm{b}}$ & $60.0^{\mathrm{a}}$ & $53.33^{\mathrm{a}}$ & $66.67^{\mathrm{b}}$ & $51.67^{\mathrm{b}}$ \\
\hline \multicolumn{7}{|c|}{ Septoria lycopersici } \\
\hline $\mathrm{T}_{0}$ & $6.67^{\mathrm{b}}$ & $28.33^{\mathrm{b}}$ & $20.0^{\mathrm{a}}$ & $33.33^{\mathrm{a}}$ & $20.0^{\mathrm{a}}$ & $31.37^{\mathrm{a}}$ \\
\hline $\mathrm{T}_{1}$ & $40.0^{\mathrm{a}}$ & $45.0^{\mathrm{a}}$ & $0.0^{\mathrm{b}}$ & $25.0^{\mathrm{b}}$ & $6.67^{\mathrm{a}}$ & $26.67^{\mathrm{b}}$ \\
\hline $\mathrm{T}_{2}$ & $6.67^{\mathrm{b}}$ & $25.0^{\mathrm{b}}$ & $20.0^{\mathrm{a}}$ & $33.33^{\mathrm{a}}$ & $0.0^{\mathrm{b}}$ & $25.0^{\mathrm{b}}$ \\
\hline $\mathrm{T}_{3}$ & $13.33^{\mathrm{b}}$ & $28.33^{\mathrm{b}}$ & $6.67^{\mathrm{a}}$ & $30.0^{\mathrm{a}}$ & $0.0^{\mathrm{b}}$ & $25.0^{\mathrm{b}}$ \\
\hline
\end{tabular}

$T_{0}, N-P-K$ (20-10-10) applied on the soil; $T_{1}, T_{0}+$ soil application of calcium nitrate + foliar sprays of calcium solution; $T_{2}$, $T_{0}+$ soil application of calcium nitrate + foliar sprays of magnesium solution; $T_{3}, T_{0}+$ soil application of calcium nitrate + foliar sprays of calcium and magnesium solutions. Values bearing different letters in the same column and for the same fungus are statistically different at $P<0.05$.

making host plant less susceptible to enzymatic degradation (Olsson, 1998, Henn, 2004). Application of $\mathrm{T}_{3}$ to tomato plants reduced the severity of early blight infection. This could be due to the presence of magnesium in the mixture. In fact magnesium fertilization has been reported to strengthen the resistance against early blight pathogen (Elfrich, 2010). Our results also suggest that early blight symptoms can be reduced through nutrition by foliar $\mathrm{Ca}^{+}$ spray. This present study may be of help in the integrated control of the disease in tomato plants. Because the $\mathrm{Ca}$ and $\mathrm{Mg}$ - related resistance to the disease is not well documented, further experiments should be conducted. No significant effect of mineral fertilizers tested was found on the incidence and severity of late blight. This corroborates with Duvenhage et al. (1992) who found no influence of calcium and magnesium amendment on disease severity of Phytophthora cinnamomi.

\section{Plant growth, development and yield}

Simultaneous applications of calcium nitrate at $200 \mathrm{~kg} / \mathrm{ha}$ on the soil and foliar sprays of solu- 


\section{Aghofack-Nguemezi et al.}

Table 2: Effects of calcium and magnesium containing fertilizers on the incidence and severity of tomato fungal diseases $\mathbf{1 4}$ days after the first foliar application of liquid fertilizers

\begin{tabular}{|c|c|c|c|c|c|c|}
\hline \multirow{3}{*}{$\begin{array}{l}\text { Fungi types and } \\
\text { treatments }\end{array}$} & \multicolumn{6}{|c|}{ Tomato varieties, incidence and severity of the fungal diseases } \\
\hline & \multicolumn{2}{|c|}{ Rio Grande } & \multicolumn{2}{|c|}{ Rio de Grenier } & \multicolumn{2}{|c|}{ Roma Savana } \\
\hline & $\begin{array}{c}\text { Incidence } \\
(\%)\end{array}$ & $\begin{array}{c}\text { Severity } \\
(\%)\end{array}$ & $\begin{array}{c}\text { Incidence } \\
(\%)\end{array}$ & $\begin{array}{c}\text { Severity } \\
(\%)\end{array}$ & $\begin{array}{c}\text { Incidence } \\
(\%)\end{array}$ & $\begin{array}{c}\text { Severity } \\
(\%)\end{array}$ \\
\hline \multicolumn{7}{|l|}{ Alternaria solani } \\
\hline $\mathrm{T}_{0}$ & $100^{\mathrm{a}}$ & $90.0^{\mathrm{a}}$ & $100^{\mathrm{a}}$ & $86.67^{\mathrm{a}}$ & $100^{\mathrm{a}}$ & $90.0^{\mathrm{a}}$ \\
\hline $\mathrm{T}_{1}$ & $100^{\mathrm{a}}$ & $88.33^{\mathrm{a}}$ & $100^{\mathrm{a}}$ & $90.33^{\mathrm{a}}$ & $100^{\mathrm{a}}$ & $93.33^{\mathrm{a}}$ \\
\hline $\mathrm{T}_{2}$ & $100^{\mathrm{a}}$ & $90.0^{\mathrm{a}}$ & $100^{\mathrm{a}}$ & $93.33^{\mathrm{a}}$ & $100^{\mathrm{a}}$ & $93.33^{\mathrm{a}}$ \\
\hline $\mathrm{T}_{3}$ & $100^{\mathrm{a}}$ & $83.33^{\mathrm{a}}$ & $100^{\mathrm{a}}$ & $86.67^{\mathrm{a}}$ & $100^{\mathrm{a}}$ & $91.67^{\mathrm{a}}$ \\
\hline \multicolumn{7}{|l|}{ Fulvia fulva } \\
\hline $\mathrm{T}_{0}$ & $0.0^{\mathrm{a}}$ & $25.0^{\mathrm{a}}$ & $6.67^{\mathrm{a}}$ & $30.0^{\mathrm{a}}$ & $0.0^{\mathrm{a}}$ & $25.0^{\mathrm{a}}$ \\
\hline $\mathrm{T}_{1}$ & $0.0^{\mathrm{a}}$ & $25.0^{\mathrm{a}}$ & $0.0^{\mathrm{a}}$ & $25.0^{\mathrm{a}}$ & $6.67^{\mathrm{a}}$ & $30.0^{\mathrm{a}}$ \\
\hline $\mathrm{T}_{2}$ & $13.33^{\mathrm{a}}$ & $30.0^{\mathrm{a}}$ & $0.0^{\mathrm{a}}$ & $25.0^{\mathrm{a}}$ & $0.0^{\mathrm{a}}$ & $25.0^{\mathrm{a}}$ \\
\hline $\mathrm{T}_{3}$ & $0.0^{\mathrm{a}}$ & $25.0^{\mathrm{a}}$ & $0.0^{\mathrm{a}}$ & $25.0^{\mathrm{a}}$ & $6.67^{\mathrm{a}}$ & $28.33^{\mathrm{a}}$ \\
\hline \multicolumn{7}{|c|}{ Phytophthora infestans } \\
\hline $\mathrm{T}_{0}$ & $73.33^{\mathrm{a}}$ & $56.67^{\mathrm{a}}$ & $60.0^{\mathrm{a}}$ & $53.33^{\mathrm{a}}$ & $60.0^{\mathrm{a}}$ & $56.67^{\mathrm{a}}$ \\
\hline $\mathrm{T}_{1}$ & $100^{\mathrm{a}}$ & $66.67^{\mathrm{a}}$ & $60.0^{\mathrm{a}}$ & $45.0^{\mathrm{a}}$ & $80.0^{\mathrm{a}}$ & $55.0^{\mathrm{a}}$ \\
\hline $\mathrm{T}_{2}$ & $93.33^{\mathrm{a}}$ & $60.0^{\mathrm{a}}$ & $86.67^{\mathrm{a}}$ & $61.67^{\mathrm{a}}$ & $93.33^{\mathrm{a}}$ & $63.33^{\mathrm{a}}$ \\
\hline $\mathrm{T}_{3}$ & $60.0^{\mathrm{a}}$ & $41.67^{\mathrm{a}}$ & $80.0^{\mathrm{a}}$ & $60.0^{\mathrm{a}}$ & $73.33^{\mathrm{a}}$ & $53.33^{\mathrm{a}}$ \\
\hline \multicolumn{7}{|c|}{ Septoria lycopersici } \\
\hline $\mathrm{T}_{0}$ & $13.33^{\mathrm{b}}$ & $31.67^{\mathrm{b}}$ & $26.67^{\mathrm{a}}$ & $35.0^{\mathrm{a}}$ & $20.0^{\mathrm{a}}$ & $30.0^{\mathrm{a}}$ \\
\hline $\mathrm{T}_{1}$ & $40.0^{\mathrm{a}}$ & $41.67^{\mathrm{a}}$ & $6.67^{\mathrm{a}}$ & $28.33^{\mathrm{a}}$ & $6.67^{\mathrm{a}}$ & $26.67^{\mathrm{a}}$ \\
\hline $\mathrm{T}_{2}$ & $26.67^{b}$ & $33.33^{\mathrm{b}}$ & $20.0^{\mathrm{a}}$ & $31.67^{\mathrm{a}}$ & $0.0^{\mathrm{b}}$ & $0.0^{\mathrm{b}}$ \\
\hline $\mathrm{T}_{3}$ & $20.0^{\mathrm{b}}$ & $30.0^{\mathrm{b}}$ & $6.67^{\mathrm{a}}$ & $28.33^{\mathrm{a}}$ & $0.0^{\mathrm{b}}$ & $0.0^{\mathrm{b}}$ \\
\hline
\end{tabular}

tions of liquid fertilizers containing $\mathrm{Ca}^{2+}$ or $\mathrm{Mg}^{2+}\left(\mathrm{T}_{3}\right)$ induced significant increases in the height of tomato plants of varieties Rio Grande $(67.2 \mathrm{~cm})$ and Rio de Grenier $(62.5 \mathrm{~cm})$ as compared to controls ( $57.9 \mathrm{~cm}$ and $59.0 \mathrm{~cm}$ respectively) and plants that received other treatments (Table 4). All treatments used rather led to an inhibition of the growth in length of Roma tomato plants $(51.0 \mathrm{~cm}, 56.4 \mathrm{~cm}$ and $55.6 \mathrm{~cm}$ respectively) in comparison to controls $(58.1 \mathrm{~cm})$. Rio de Grenier plants that received any of the three treatments applied set fruits significantly earlier $(38,38$ and 39 days respectively after transplantation) than control plants (41 days after transplantation). Calcium nitrate at $200 \mathrm{~kg} / \mathrm{ha}$ and foliar sprays of liquid fertilizer containing $\mathrm{Ca}^{2+}\left(\mathrm{T}_{1}\right)$ induced a significant reduction of the length of the period between the pricking out and the formation of the first fruits by treated Rio Grande (43 days after transplantation) and Roma (35 days after transplantation) plants in comparison to controls (45 and 37 days respectively after transplantation) and plants that received other types of mineral fertilizers. Rio Grande and Rio de Grenier plants which previously received $T_{3}$ yielded significant greater quantities of fruits (4.6 and $11.3 \mathrm{t} / \mathrm{ha}$ respectively) than controls (3.8 and $8.8 \mathrm{t} / \mathrm{ha}$ respectively) and plants that received other types of mineral fertilizers. Applications 
Table 3: Effects of calcium and magnesium containing fertilizers on the incidence and severity of tomato fungal diseases 21 days after the first foliar application of liquid fertilizers

\begin{tabular}{|c|c|c|c|c|c|c|}
\hline \multirow{3}{*}{$\begin{array}{l}\text { Fungi types and } \\
\text { treatments }\end{array}$} & \multicolumn{6}{|c|}{ Tomato varieties, incidence and severity of the fungal diseases } \\
\hline & \multicolumn{2}{|c|}{ Rio Grande } & \multicolumn{2}{|c|}{ Rio de Grenier } & \multicolumn{2}{|c|}{ Roma Savana } \\
\hline & $\begin{array}{c}\text { Incidence } \\
(\%)\end{array}$ & $\begin{array}{c}\text { Severity } \\
(\%)\end{array}$ & $\begin{array}{c}\text { Incidence } \\
(\%)\end{array}$ & $\begin{array}{c}\text { Severity } \\
(\%)\end{array}$ & $\begin{array}{c}\text { Incidence } \\
(\%)\end{array}$ & $\begin{array}{c}\text { Severity } \\
(\%)\end{array}$ \\
\hline \multicolumn{7}{|l|}{ Alternaria solani } \\
\hline $\mathrm{T}_{0}$ & $100^{\mathrm{a}}$ & $95.0^{\mathrm{a}}$ & $100^{\mathrm{a}}$ & $88.33^{\mathrm{a}}$ & $100^{\mathrm{a}}$ & $95.0^{\mathrm{a}}$ \\
\hline $\mathrm{T}_{1}$ & $100^{\mathrm{a}}$ & $93.33^{\mathrm{a}}$ & $100^{\mathrm{a}}$ & $95.0^{\mathrm{a}}$ & $100^{\mathrm{a}}$ & $90.0^{\mathrm{b}}$ \\
\hline $\mathrm{T}_{2}$ & $100^{\mathrm{a}}$ & $95.0^{\mathrm{a}}$ & $100^{\mathrm{a}}$ & $95.0^{\mathrm{a}}$ & $100^{\mathrm{a}}$ & $96.67^{\mathrm{a}}$ \\
\hline $\mathrm{T}_{3}$ & $100^{\mathrm{a}}$ & $86.67^{\mathrm{b}}$ & $100^{\mathrm{a}}$ & $80.0^{\mathrm{b}}$ & $100^{\mathrm{a}}$ & $91.67^{\mathrm{b}}$ \\
\hline \multicolumn{7}{|l|}{ Fulvia fulva } \\
\hline $\mathrm{T}_{0}$ & $26.67^{\mathrm{a}}$ & $45.0^{\mathrm{a}}$ & $40.0^{\mathrm{a}}$ & $55.0^{\mathrm{a}}$ & $13.33^{\mathrm{a}}$ & $38.33^{\mathrm{a}}$ \\
\hline $\mathrm{T}_{1}$ & $6.67^{\mathrm{b}}$ & $31.67^{\mathrm{a}}$ & $20.0^{\mathrm{b}}$ & $40.0^{\mathrm{b}}$ & $6.67^{\mathrm{a}}$ & $30.0^{\mathrm{a}}$ \\
\hline $\mathrm{T}_{2}$ & $20.0^{\mathrm{a}}$ & $31.67^{\mathrm{a}}$ & $20.0^{\mathrm{b}}$ & $40.0^{\mathrm{b}}$ & $0.0^{\mathrm{b}}$ & $25.0^{\mathrm{b}}$ \\
\hline $\mathrm{T}_{3}$ & $0.0^{\mathrm{b}}$ & $25.0^{\mathrm{b}}$ & $6.67^{\mathrm{b}}$ & $30.0^{\mathrm{b}}$ & $26.67^{\mathrm{a}}$ & $38.33^{\mathrm{a}}$ \\
\hline \multicolumn{7}{|c|}{ Phytophthora infestans } \\
\hline $\mathrm{T}_{0}$ & $80.0^{\mathrm{a}}$ & $63.33^{\mathrm{a}}$ & $73.33^{\mathrm{a}}$ & $50.0^{\mathrm{a}}$ & $60.0^{\mathrm{a}}$ & $60.0^{\mathrm{a}}$ \\
\hline $\mathrm{T}_{1}$ & $93.33^{\mathrm{a}}$ & $56.67^{\mathrm{a}}$ & $60.0^{\mathrm{a}}$ & $48.33^{\mathrm{a}}$ & $86.67^{\mathrm{a}}$ & $61.67^{\mathrm{a}}$ \\
\hline $\mathrm{T}_{2}$ & $86.67^{\mathrm{a}}$ & $55.0^{\mathrm{a}}$ & $86.67^{\mathrm{a}}$ & $60.0^{\mathrm{a}}$ & $93.33^{\mathrm{a}}$ & $60.0^{\mathrm{a}}$ \\
\hline $\mathrm{T}_{3}$ & $60.0^{\mathrm{a}}$ & $41.67^{\mathrm{a}}$ & $80.0^{\mathrm{a}}$ & $58.33^{\mathrm{a}}$ & $66.67^{\mathrm{a}}$ & $50.0^{\mathrm{a}}$ \\
\hline \multicolumn{7}{|c|}{ Septoria lycopersici } \\
\hline $\mathrm{T}_{0}$ & $33.33^{\mathrm{a}}$ & $43.33^{\mathrm{a}}$ & $33.33^{\mathrm{a}}$ & $41.67^{\mathrm{a}}$ & $0.0^{\mathrm{a}}$ & $30.0^{\mathrm{a}}$ \\
\hline $\mathrm{T}_{1}$ & $33.33^{\mathrm{a}}$ & $31.67^{\mathrm{a}}$ & $6.67^{\mathrm{a}}$ & $26.67^{\mathrm{a}}$ & $0.0^{\mathrm{a}}$ & $25.0^{\mathrm{a}}$ \\
\hline $\mathrm{T}_{2}$ & $13.33^{\mathrm{a}}$ & $25.0^{\mathrm{a}}$ & $13.33^{\mathrm{a}}$ & $30.0^{\mathrm{a}}$ & $0.0^{\mathrm{a}}$ & $25.0^{\mathrm{a}}$ \\
\hline $\mathrm{T}_{3}$ & $6.67^{\mathrm{a}}$ & $28.33^{\mathrm{a}}$ & $6.67^{\mathrm{a}}$ & $28.33^{\mathrm{a}}$ & $0.0^{\mathrm{a}}$ & $25.0^{\mathrm{a}}$ \\
\hline
\end{tabular}

$T_{0}, N-P-K$ (20-10-10) applied on the soil; $T_{1}, T_{0}+$ soil application of calcium nitrate + foliar sprays of calcium solution; $T_{2}$, $T_{0}+$ soil application of calcium nitrate + foliar sprays of magnesium solution; $T_{3}, T_{0}+$ soil application of calcium nitrate + foliar sprays of calcium and magnesium solutions. Values bearing different letters in the same column and for the same fungus are statistically different at $P<0.05$.

of calcium nitrate at $200 \mathrm{~kg} / \mathrm{ha}$ on the soil and foliar sprays of the liquid fertilizer containing $\mathrm{Ca}^{2+}\left(\mathrm{T}_{1}\right)$ or $\mathrm{Mg}^{2+}\left(\mathrm{T}_{2}\right)$ induced significant increases in the fruit yield of treated Roma plants (7.6 and $8.3 \mathrm{t} /$ ha respectively) when compared to controls $(5.8 \mathrm{t} / \mathrm{ha})$ and plants that received $\mathrm{T}_{3}$ $\left(\mathrm{Ca}^{2+}\right.$ and $\left.\mathrm{Mg}^{2+}\right)$ (Table 4).

Thus, $\mathrm{T}_{3}$ was more effective in enhancing the growth and yield parameters of the two tomato varieties Rio Grande and Rio de Grenier plants whereas $T_{2}$ and $T_{1}$ induced significant increases in the yield of Roma plants. Obviously the closely related Rio Grande and Rio de Grenier tomato varieties had similar physiological exi- gencies toward calcium and magnesium ions for their growth and fruit yield. The efficient physiological concentration balance of the two divalent ions was probably reached by combining an application of calcium nitrate on the soil with foliar sprays of liquid fertilizers containing calcium or magnesium during the growth and development phases of Rio Grande and Rio de Grenier. Roma tomato plants didn't seemingly require a combination of calcium and magnesium for an optimum fruit yield. The physiological relationship between calcium and magnesium might be mediated by the phytohormone abscissic acid (ABA). It is well established that ABA signaling involves calcium- 
Table 4: Effects of calcium and magnesium containing fertilizers on tomato plant growth, development and yield parameters

\begin{tabular}{lcccc}
\hline $\begin{array}{l}\text { Varieties and } \\
\text { treatments }\end{array}$ & $\begin{array}{c}\text { Height } \\
(\mathbf{c m})\end{array}$ & $\begin{array}{c}\text { Period between the } \\
\text { pricking out and flow- } \\
\text { ering of 50\% of plants } \\
\text { (days) }\end{array}$ & $\begin{array}{c}\text { Period between the } \\
\text { pricking out and } \\
\text { fruiting of plants } \\
(\text { days })\end{array}$ & $\begin{array}{c}\text { Yield } \\
(\mathbf{t} / \mathbf{h a})\end{array}$ \\
\hline Rio Grande & $57.9 \pm 2.5^{\mathrm{b}}$ & $38 \pm 2^{\mathrm{a}}$ & $45 \pm 2^{\mathrm{a}}$ & \\
$\mathrm{T}_{0}$ & $61.0 \pm 19.0^{\mathrm{b}}$ & $38 \pm 2^{\mathrm{a}}$ & $43 \pm 2^{\mathrm{b}}$ & $3.8 \pm 0.9^{\mathrm{b}}$ \\
$\mathrm{T}_{1}$ & $58.1 \pm 8.5^{\mathrm{b}}$ & $39 \pm 0^{\mathrm{a}}$ & $44 \pm 2^{\mathrm{a}}$ & $3.6 \pm 1.1^{\mathrm{b}}$ \\
$\mathrm{T}_{2}$ & $67.2 \pm 3.5^{\mathrm{a}}$ & $40 \pm 2^{\mathrm{a}}$ & $45 \pm 0^{\mathrm{a}}$ & $4.6 \pm 1.7^{\mathrm{b}}$ \\
$\mathrm{T}_{3}$ & & & & \\
$\mathrm{Rio} \mathrm{de} \mathrm{Grenier}_{\mathrm{T}}$ & $59.0 \pm 1.2^{\mathrm{b}}$ & $36 \pm 1^{\mathrm{a}}$ & $41 \pm 2^{\mathrm{a}}$ & $8.8 \pm 0.8^{\mathrm{b}}$ \\
$\mathrm{T}_{1}$ & $59.9 \pm 9.8^{\mathrm{b}}$ & $35 \pm 1^{\mathrm{a}}$ & $38 \pm 1^{\mathrm{b}}$ & $9.6 \pm 6.1^{\mathrm{b}}$ \\
$\mathrm{T}_{2}$ & $60.4 \pm 9.4^{\mathrm{b}}$ & $35 \pm 1^{\mathrm{a}}$ & $38 \pm 1^{\mathrm{b}}$ & $9.5 \pm 1.3^{\mathrm{b}}$ \\
$\mathrm{T}_{3}$ & $62.5 \pm 0.5^{\mathrm{a}}$ & $36 \pm 2^{\mathrm{a}}$ & $39 \pm 1^{\mathrm{b}}$ & $11.3 \pm 1.2^{\mathrm{a}}$ \\
$\mathrm{Roma} \mathrm{savana}_{\mathrm{T}_{0}}$ & $58.1 \pm 8.5^{\mathrm{a}}$ & $34 \pm 2^{\mathrm{a}}$ & & \\
$\mathrm{T}_{1}$ & $51.0 \pm 8.8^{\mathrm{b}}$ & $35 \pm 2^{\mathrm{a}}$ & $37 \pm 1^{\mathrm{a}}$ & $5.8 \pm 0.1^{\mathrm{b}}$ \\
$\mathrm{T}_{2}$ & $56.4 \pm 17.5^{\mathrm{b}}$ & $36 \pm 3^{\mathrm{a}}$ & $35 \pm 0^{\mathrm{b}}$ & $7.6 \pm 0.8^{\mathrm{a}}$ \\
$\mathrm{T}_{3}$ & $55.6 \pm 22.2^{\mathrm{b}}$ & $34 \pm 1^{\mathrm{a}}$ & $38 \pm 1^{\mathrm{a}}$ & $8.3 \pm 1.0^{\mathrm{a}}$ \\
\hline
\end{tabular}

$T_{0}, N-P-K$ (20-10-10) applied on the soil; $T_{1}, T_{0}+$ soil application of calcium nitrate + foliar sprays of calcium solution; $T_{2}$, $T_{0}+$ soil application of calcium nitrate + foliar sprays of magnesium solution; $T_{3}, T_{0}+$ soil application of calcium nitrate + foliar sprays of calcium and magnesium solutions. Values bearing different letters in the same column and for the same tomato variety are statistically different at $P<0.05$.

dependent pathways (Taiz and Zeiger, 2006) and that the enzymes kinases promote the activation of the $\mathrm{Ca}^{2+}$ channel in cells (Assmann, 2007). Magnesium that activates many dehydrogenases and phosphate transfer enzymes (Öpik and Rolfe, 2005) may stimulate the effects of calcium and/or ABA on fruit yield since ABA regulates fruit maturation, seed storage reserve accumulation and induces protein synthesis in seeds (Davies, 2007; Taiz and Zeiger, 2006). ABA found in fruits is used mainly in environmental stress to move calcium to tomato fruits (Setha, 2012; Waterland et al., 2010). ABA reduces the xylem activity of leaves and increases the phloem activity, thus reorienting more calcium to the tomato fruits rather than leaf tissues (de Fratas et al., 2011). The increased calcium concentration may in turn stimulate the promoting role of $\mathrm{ABA}$ in fruit growth and development. Besides its interference in ABA action, calcium ion is a well known component of plant signal transduction (Buchanan et al., 2000). It is therefore involved in the control and regulation of various processes related to plant growth and development, and the maturation and ripening of fruits.

\section{Fruit quality}

There was no significant change in the water content of fruits produced by plants that received fertilizers containing $\mathrm{Ca}^{2+}$ or $\mathrm{Mg}^{2+}$ when compared to fruits produced by control plants. Rio Grande, Rio de Grenier and Roma plants that previously received $\mathrm{T}_{1}$ subsequently produced fruits whose $\mathrm{Ca}^{2+}$ content was significantly higher (respectively 28.2, 33.3 and 29.5 $\mathrm{meq} / \mathrm{kg}$ ) than that of controls (respectively $22.4,28.2$ and $25.7 \mathrm{meq} / \mathrm{kg}$ ) and fruits from 
other treated plants (Table 5). No significant alteration in the endogenous level of $\mathrm{Mg}^{2+}$ in fruits produced by all the three varieties of tomato plants as related to applications of fertilizers containing calcium or magnesium was observed. Fruits produced by Rio Grande and Rio de Grenier plants that previously received $\mathrm{T}_{1}$ or $\mathrm{T}_{3}$ showed a longer green-life (24 and 25 days respectively) for Rio Grande, 18 and 16 days for Rio de Grenier) as compared to fruits produced by control plants (14 and 12 days respectively). All the three types of fertilizers tested didn't significantly affect the green-life of fruits produced by Roma tomato plants. The application of $\mathrm{T}_{2}$ induced significant increases in the shelf-life of fruits produced by Rio Grande (79 days) and Rio de Grenier (75 days) as compared to fruits from control plants (75 and 63 respectively). Fruits produced by Roma plants that previously received $T_{1}$ and $T_{3}$ had significantly longer shelf-life ( 75 and 73 days respectively) than fruits produced by controls (62 days) and plants that received $\mathrm{T}_{2}$ (Table 5).

Fruit ripening is a result of many processes including the softening of cell walls and membranes, chlorophyll breakdown and synthesis of new carotenoids (Giovannoni, 2001; Brady, 1987). In the mature treated tomato fruits, calcium ions could bind with the negatively charged carboxylic groups in pectin to form cross bridges in the cell wall and membrane complexes (Magee et al., 2003; Leshem, 1991). These cross bridges reinforce the rigidity of the cell wall (Leshem, 1991) and inhibit the activity of pectinmethylesterase and polygalaturo-

Table 5: Effects of calcium and magnesium containing fertilizers on tomato fruit quality parameters

\begin{tabular}{|c|c|c|c|c|c|}
\hline $\begin{array}{l}\text { Varieties and } \\
\text { treatments }\end{array}$ & $\begin{array}{c}\text { Water content } \\
(\%)\end{array}$ & $\begin{array}{l}\text { Calcium content } \\
(\mathrm{meq} / \mathrm{kg})\end{array}$ & $\begin{array}{c}\text { Magnesium } \\
\text { content } \\
(\mathrm{meq} / \mathrm{kg})\end{array}$ & $\begin{array}{l}\text { Green-life } \\
\text { (days) }\end{array}$ & $\begin{array}{l}\text { Shelf-life } \\
\text { (days) }\end{array}$ \\
\hline \multicolumn{6}{|l|}{ Rio Grande } \\
\hline $\mathrm{T}_{0}$ & $88.1 \pm 1.4^{\mathrm{a}}$ & $22.4 \pm 3.2^{\mathrm{b}}$ & $19.4 \pm 2.9^{\mathrm{a}}$ & $14 \pm 1^{\mathrm{b}}$ & $75 \pm 5^{\mathrm{b}}$ \\
\hline $\mathrm{T} 1$ & $88.3 \pm 1.5^{\mathrm{a}}$ & $28.2 \pm 1.5^{\mathrm{a}}$ & $19.5 \pm 1.3^{\mathrm{a}}$ & $24 \pm 3^{\mathrm{a}}$ & $64 \pm 11^{\mathrm{b}}$ \\
\hline $\mathrm{T}_{2}$ & $87.1 \pm 2.4^{\mathrm{a}}$ & $21.0 \pm 4.6^{\mathrm{b}}$ & $18.9 \pm 5.0^{\mathrm{a}}$ & $15 \pm 4^{\mathrm{b}}$ & $79 \pm 2^{\mathrm{a}}$ \\
\hline $\mathrm{T}_{3}$ & $90.3 \pm 2.4^{\mathrm{a}}$ & $25.9 \pm 5.9^{b}$ & $19.1 \pm 5.0^{\mathrm{a}}$ & $25 \pm 2^{\mathrm{a}}$ & $70 \pm 9^{\mathrm{b}}$ \\
\hline \multicolumn{6}{|l|}{ Rio de Grenier } \\
\hline $\mathrm{T}_{0}$ & $88.9 \pm 1.5^{\mathrm{a}}$ & $28.2 \pm 1.5^{\mathrm{b}}$ & $15.4 \pm 3.7^{\mathrm{a}}$ & $12 \pm 1^{b}$ & $63 \pm 3^{\mathrm{b}}$ \\
\hline $\mathrm{T}_{1}$ & $88.9 \pm 1.7^{\mathrm{a}}$ & $33.3 \pm 1.2^{\mathrm{a}}$ & $17.3 \pm 8.4^{\mathrm{a}}$ & $18 \pm 2^{\mathrm{a}}$ & $59 \pm 3^{\mathrm{b}}$ \\
\hline $\mathrm{T}_{2}$ & $89.7 \pm 1.5^{\mathrm{a}}$ & $27.2 \pm 8.1^{\mathrm{b}}$ & $17.7 \pm 5.9^{\mathrm{a}}$ & $14 \pm 3^{b}$ & $75 \pm 2^{a}$ \\
\hline & $89.1 \pm 1.0^{\mathrm{a}}$ & $28.7 \pm 1.8^{\mathrm{b}}$ & $17.1 \pm 5.2^{\mathrm{a}}$ & $16 \pm 1^{a}$ & $54 \pm 10^{\mathrm{b}}$ \\
\hline \multicolumn{6}{|l|}{ Roma Savana } \\
\hline $\mathrm{T}_{0}$ & $86.9 \pm 0.5^{\mathrm{a}}$ & $25.7 \pm 0.8^{\mathrm{b}}$ & $16.8 \pm 7.2^{\mathrm{a}}$ & $8 \pm 1^{\mathrm{a}}$ & $62 \pm 2^{b}$ \\
\hline $\mathrm{T}_{1}$ & $88.2 \pm 0.5^{\mathrm{a}}$ & $29.5 \pm 1.2^{\mathrm{a}}$ & $16.0 \pm 4.6^{\mathrm{a}}$ & $7 \pm 1^{\mathrm{a}}$ & $75 \pm 3^{\mathrm{a}}$ \\
\hline $\mathrm{T}_{2}$ & $88.0 \pm 0.8^{\mathrm{a}}$ & $26.5 \pm 6.0^{\mathrm{b}}$ & $17.1 \pm 2.2^{\mathrm{a}}$ & $10 \pm 1^{\mathrm{a}}$ & $58 \pm 4^{\mathrm{b}}$ \\
\hline $\mathrm{T}_{3}$ & $85.3 \pm 0.5^{\mathrm{a}}$ & $26.3 \pm 2.3^{b}$ & $17.7 \pm 6.2^{\mathrm{a}}$ & $9 \pm 4^{\mathrm{a}}$ & $73 \pm 5^{\mathrm{a}}$ \\
\hline
\end{tabular}

$T_{0}, N-P-K$ (20-10-10) applied on the soil; $T_{1}, T_{0}+$ soil application of calcium nitrate + foliar sprays of calcium solution; $T_{2}$, $T_{0}+$ soil application of calcium nitrate + foliar sprays of magnesium solution; $T_{3}, T_{0}+$ soil application of calcium nitrate + foliar sprays of calcium and magnesium solutions. Values bearing different letters in the same column and for the same tomato variety are statistically different at $P<0.05$. 


\section{Aghofack-Nguemezi et al.}

nase which are enzymes implied in the degradation of the cell wall pectin (Magee et al., 2003). Thus these cross bridges significantly prolong the green-life of mature fruits. Magnesium may play an important role in the maintenance of the green status of tomato fruits since it is the central atom of the ring structure of the chlorophyll molecule (Taiz and Zeiger, 2006). The green-life and shelf-life are two very distinctive phases in the life of fruits. The ripening phase that corresponds to the de-greening of peel could involve catabolic as well as anabolic activities whereas during the shelf-life of fruits metabolic processes are largely catabolic. In fact, in chromoplasts, the plastids of ripening fruits, aside the breakdown of chlorophyll and other catabolic reactions there is an intensive biosynthesis of new carotenoids. In contrast to chromoplasts, the metabolism of senescencespecific forms of plastids (gerontoplasts) is solely catabolic (Matile and Hörtensteiner, 1999). The overall metabolism of the shelf-life of tomato fruit is certainly similar to that of leaf senescence in natural conditions. These might be some of the reasons why different treatments in the field were effective in enhancing the green-life and the shelf-life of tomato fruits. The fact that the green- and shelf-life of fruits produced by Rio Grande and Rio de Grenierwere affected in similar manner by applications of fertilizers containing calcium or magnesium could explain close genetic relationships between the two varieties.

\section{CONCLUSION}

On the whole, the inducing effects of the mineral fertilizers tested on the resistance of treated tomato plants to late blight and septoria leaf spot were visible seven days after the first foliar application (d.a.f.a) of liquid fertilizers whereas it was later on 21 d.a.f.a that the positive effects of these fertilizers could be observed on the incidence and the severity of early blight and leaf mould. Furthermore, the two tomato varieties Rio Grande and Rio de Grenier showed similar and significant responses to the effects of the combined treatments of calcium nitrate in the soil and foliar spray of calcium-magne- sium solutions on the plant health, growth and yield, the green-life and shelf-life of fruits. However, weaker responses were observed in the Roma tomato plants.

\section{REFERENCES}

Aghofack-Nguemezi, J. and Tatchago, V. (2010). Effects of fertilizers containing calcium and/or magnesium on the growth, development of plants and the quality of tomato fruits in the Western Highlands of Cameroon. International Journal of Agricultural Research5(10): 821-831.

Assmann, S. M. (2007). Abscissicacid signal transduction in stomatal responses. In: Davies, P. J. (Editor). Plant hormones: biosynthesis, signal transduction and action. Springer, Dordrecht, Netherlands.

Brady, C. J. (1987). Fruit ripening. Annual Review of Plant physiology 38: 155-178.

Buchanan, B. B., Gruissem, W. and Jones, R. L. (2000). Biochemistry and molecular biology of plants. American Society of Plant physiologists, Rockville.

Chapman, S. B. (1976). Methods in Plant Ecology. Physiology and Nutrition. Blackwell Scientific Publications, Oxford.

Dadzie, B. K. and Ochard, J. E. (1997). Rapid post harvest screening of banana/plantain hybrids: Criteria and methods. INIBAB technical guidelines 2. International Plant $\mathrm{Ge}$ netic Resources Institute, Rome, Italy; International Network for the Improvement of Banana and Plantain, Montpellier, France; ACP-EU Technical Centre for Rural Cooperation, Wageningen, The Netherlands.

Davies, P. J. (2007). The plant hormones: their nature, occurrence and functions. In: Davies, P. J. (Editor). Plant hormones: biosynthesis, signal transduction and action. Springer, Dordrecht, The Netherlands. 
Duvenhage, J. A., Kotzé, J. M. and Erna, M. C. (1992). The influence of nitrogen and calcium on mycelial growth and disease severity of Phytophthoracinnamomi and the effect of calcium on resistance of avocado to root rot. South African Avocado Growers' Association Yearbook 15: 12-14.

Elfrich, R. (2010). Magnesium fertilisation strengthens the resistance against Alternaria. Retrieved on the $13^{\text {th }}$ February, 2014 from http://www.kaligmbh.com/uken/fertiliser/ news/news_20100825_potato_alternaria.html

Fontem, D. A. (1993). Survey of tomato diseases in Cameroon. Tropicultura 11(3): 8790.

deFreitas, S. T., Shackel, K. A. and Mitcham, E. J. (2011). Abscissic acid triggers wholeplant and fruit-specific mechanisms to increase fruit calcium uptake and prevent blossom end rot development in tomato. Journal of Experimental Botany 62(8): 2654-2656.

Friedman, H., Goldschmidt, E. E. and Halevy A. H. (1989). Involvement of calcium in the photoperiodic flower induction process of Pharbitisnil. Plant Physiology 89(2): 530534.

Giovannoni, J. (2001). Molecular biology of fruit maturation and ripening. Annual Review of Plant Physiology and Plant Molecular Biology 52: 725-749.

Hao, X. M. and Papadopoulos, A. P. (2004). Effects of calcium and magnesium on plant growth, biomass partitioning and fruit yield of winter greenhouse tomato. Hort Science 39(3): 512-515.

Henn, A. (2004).The Plant Doctor. Plant Disease and Fertilization. Mississippi State University Extension Service, Mississippi.

Hepler, P. K. (2005). Calcium: A central regulator of plant growth and development. Plant
Cell 17(8): 2142-2155.

Hepler, P. K. and Wayne, R. O. (1985). Calcium and plant development. Annual Review of Plant Physiology 36: 397-439.

Kobayashi, N. I., Tanoi, K. and Nakanishi, T. M. (2006). Magnesium localization in shoot apices during flower induction in Phabitisnil. Canadian Journal of Botany 84(12): 1908 1916.

Leshem, Y. Y. (1991). Plant membrane senescence. In: Penel, $\mathrm{C}$. and Greppin, $\mathrm{H}$. (Editors). Plant signaling, plasma membrane and change of state. University of Geneva Press, Geneva.

Magee, R. I., Caporaso, F. and Prakash, A. (2003). Effects of exogenous calcium salt treatments on inhibiting irradiation-induced softening in diced Roma tomatoes. Journal of Food Science 68(8): 2430-2435.

Matile, P. and Hörtensteiner, S. (1999). Chlorophyll degradation. Annual Review of Plant Physiology and Plant Molecular Biology 50: 67-95.

Merrit, R., Nelson, T.V., Orum V. and Ramon, J. G. (1999). Application of geographic information systems and geostatistics in plant disease epidemiology and management. Plant Diseases 83(4): 308-319.

Olsson, K. (1998). Resistance to gangrene (Phomaexigua var. foveata) and dry rot (Fusariumsolani var. coeruleum) in potato tubers.1. the influence of pectin-bound magnesium and calcium. Potato Research 31: 413-422.

Öpik, H. and Rolfe, S. (2005). The physiology of flowering plants. Cambridge University Press, Cambridge.

Park, S., Cheng, N. H., Pittman, J. K., Yao, K. S., Park, J., Smith, R. H. and Hirschi, K. D. 


\section{Aghofack-Nguemezi et al.}

(2005). Increased calcium levels and pro longed shelf-life in tomatoes expressing Arabidopsis $\mathrm{H}^{+} / \mathrm{Ca}^{2+}$ transporters. Plant Physiology 139(3): 1194-1106.

Pauwels, J. M., Van Ranst, E., Verloo, M. and MvondoZe, A. (1992). Laboratory manual of soil science. Methods of analysis of soils and plants, equipments, inventory management of Glassware and chemicals. Administration for Development Cooperation, Bruxelles.

Percival, G. C. and Haynes, I. (2009). The Influence of calcium sprays to reduce fungicide inputs against apple scab (Venturiainaequalis (cooke) G. Wint). Arboriculture and Forestry 35(5): 263-270.

Setha, S. (2012). Roles of abscissic acid in fruit ripening. Walailak J. Sci. Technol. 9(4): 297-
308.

Streets, R. B. (1982). The diagnosis of plant diseases. University of Arizona Press. Tucson, Arizona.

Taiz, L. and Zeiger, E. (2006). Plant Physiology. Sinauer Associates, Inc., Publishers, Sunderland, Massachusetts.

Waterland, N. L., Campbell, C. A., Finer, J. J. and Jones, M. L. (2010). Abscissic acid application enhances drought stress tolerance in bedding plants. HortScience 45(3): 4094013.

Zook, M. N., Rush, J. S. and Kuc, J. C. (1987). A role for $\mathrm{Ca}^{2+}$ in the elicitation of rishitin and lubimin accumulation in potato tuber tissue. Plant Physiology 84: 520-525. 